\title{
PENEGAKAN HUKUM TINDAK PIDANA KEKERASAN TERHADAP PEREMPUAN DI KOTA DEMAK
}

\author{
Aldila Arumita Sari, Ani Purwanti \\ Program Studi Magister Ilmu HukumUniversitas Diponegoro \\ aldilamita47@gmail.com
}

\begin{abstract}
Gender-based violence is a social phenomenon that existed since antiquity and increasingly rampant lately. Even violence against women, is increasing, both the number and form and mode of operation that is increasingly diverse both in the domestic (household) and public. According to the women's annual report of women in 2015 violence against women is most prominent of violence occurring within the scope of households. Cases of violence against women are higher. Especially violence against women in a more prominent household. The authors raised the question of how the formulation policy of criminal acts of violence against women and how its enforcement in the city of Demak. The author conducted the study by presenting the facts about the crime of violence against women in relation to the law in Indonesia itself using empirical juridical method. This is done to support the accuracy of data in composing this paper. Research that has been done, the results show that the formulation of protection for women in international and national instruments can be as an effort to tackle the crime of violence against women in the household sphere after the issuance of Law No. 23 of 2004. Formulation policy of protection for women in the instrument intrnasional Or national only applies when outside the scope of the household. The process of protection and law enforcement apparatus in dealing with law enforcement of violence against women in the household sphere in Demak city is not optimal yet there are still suspects that can not yet be tried.
\end{abstract}

Keywords: Crime, Violence Against Women, Demak

\begin{abstract}
Abstrak
Kekerasan berbasis gender merupakan fenomena sosial yang ada sejak jaman dahulu dan semakin marak akhir-akhir ini. Bahkan kekerasan terhadap perempuan, semakin meningkat, baik jumlah maupun bentuk dan modus operansinya yang semakin beragam baik di lingkup domestik (rumah tangga) maupun publik. Menurut catatan tahunan komnas perempuan pada tahun 2017 kekerasan terhadap perempuan yang paling menonjol kekerasan yang terjadi dalam lingkup rumah tangga. Kasus kekerasan terhadap perempuan semakin tinggi, terutama kekerasan terhadap perempuan dalam lingkup rumah tangga. Penulis mengangkat persoalan mengenai bagimana kebijakan formulasi tindak pidana kekerasan terhadap perempuan dan bagaimana penegakannya di kota Demak. Penelitian ini menggunakan metode Yuridis Empiris dengan menyuguhkan fakta-fakta mengenai tindak pidana kekerasan terhadap perempuan terkait dengan hukum yang berlaku di Indonesia dan bagaimana penangannya di Kota Demak, termasuk menyajikan pengalaman perempuan sebagai korban. Dari penelitian yang dilakukan diperoleh data bahwa Kebijakan Formulasi perlindungan bagi perempuan dalam instrument internasional dan nasional dapat digunakan sebagai upaya menanggulangi tindak pidana kekerasan terhadap perempuan dalam lingkup rumah tangga, khususnya setelah keluarnya Undang-undang No 23 tahun 2004. Regulasi perlindungan bagi perempuan dalam instrument internasional maupun nasional hanya berlaku
\end{abstract}


apabila peristiwanya terjadi di lingkup rumah tangga, sehingga korban diluar rumah tangga tidak dapat menggunakan ketentuan hokum tersebut. Rancangan Undang Undang Kekerasan Seksual diharapkan segera disyahkan untuk melindungi dan menangani perempuan korban kekerasan baik didalam rumah tangga maupun diluar rumah.Proses penegakan hokum oleh aparat penegak hukum dalam menangani penegakan hukum tindak pidana kekerasan terhadap perempuan di Kota Demak belum optimal, karena belum baiknya koordinasi diantara stakeholder (Polisi, Jaksa, Hakim, LSM Pendamping, Pemerintah Daerah Kota Demak)

Kata kunci: Tindak Pidana, Kekerasan Terhadap Perempuan, Demak

\section{A. Pendahuluan}

Kekerasan berbasis gender, semakin meningkat, baik jumlah maupun bentuk dan modus operasinya yang semakin beragam.Faktor penyebab terjadinya kekerasan berbasis gender, sangat kompleks dan satu sama lain saling berkaitan. Factorfaktor tersebut, antara lain perangkat hukum yang belum mampu memberikan perlindungan kepada para korban, konsep bahwa perempuan adalah milik keluarga (asset), media yang kurang mendukung pemberitaan tentang kekerasan terhadap perempuan dan anak, pelayanan publik yag belum optimal, adat istiadat yang kadang melegalkan kekerasan, persoalan kemiskinan, interprestasi yang keliru pada ajaran agama, yang semua itu terbungkus dalam budaya patriarkhi.(Foley, Ngo, Loi, \& Zheng, 2015)

Komisi Nasional Anti Kekerasan terhadap Perempuan (Komnas Perempuan) mengeluarkan Catatan Tahunan (Catahu) tahun 2016, untuk memperingati Hari
Perempuan Internasional setiap 8 Maret 2016. Komnas Perempuan memberikan catatan penting dan menyimpulkan bahwa pada tahun 2015 kekerasan terhadap perempuan memperlihatkan pola meluas, sehingga penting agar negara hadir secara maksimal untuk terlibat dalam pencegahan, penanganan, serta tindakan strategis untuk menjamin rasa aman perempuan korban. Temuan Komnas Perempuan mencatat bahwa kekerasan terhadap perempuan tidak hanya terjadi di ranah domestik atau rumah tangga maupun dalam relasi perkawinan, tetapi juga terjadi meluas di masyarakat umum maupun yang berdampak dari kebijakan negara.(Komnas Perempuan, 2016)

Kekerasan terhadap perempuan yang paling menonjol kekerasan terjadi di ranah personal. Ranah personal artinya pelaku adalah orang yang memiliki hubungan darah (ayah, kakak, adik, paman, kakek), kekerabatan, perkawinan (suami) maupun 
relasi intim (pacaran) dengan korban. Berdasarkan jumlah kasus sebesar 321.752 tersebut, jenis kekerasan terhadap perempuan yang paling menonjol sama seperti tahun sebelumnya adalah kekerasan yang terjadi di ranah personal sejumlah 305.535. Sementara dari 16.217 kasus yang masuk dari lembaga layanan mitra Komnas Perempuan, RP(ranah personal) tercatat $69 \%$ atau 11.207 kasus, $60 \%$ atau 6.725 kasus berupa kekerasan terhadap istri, 24\% atau 2.734 kasus kekerasan dalam pacaran, dan $8 \%$ atau 930 kasus kekerasan terhadap anak perempuan. Dalam ranah KDRT(kekerasan dalam rumah tangga) atau RP(ranah personal), kekerasan fisik menempati peringkat pertama dengan persentase $38 \%$ atau 4.304 kasus, diikuti dengan kekerasan seksual $30 \%$ atau 3.325 kasus, kekerasan psikis $23 \%$ atau 2.607, dan ekonomi 9\% atau 971 kasus. Berbeda dari catatan tahunan 2014 dimana kekerasan seksual menempati peringkat ketiga, di tahun ini naik kekerasan seksual naik di peringkat kedua. Bentuk kekerasan seksual tertinggi adalah perkosaan $72 \%$ atau 2.399 kasus, pencabulan $18 \%$ atau 601 kasus, dan pelecehan seksual 5\% atau 166 kasus.(Purwanti, 2017)

Isu kekerasan terhadap perempuan telah terbukti sebagai masalah sosial yang serius, namun masih kurang mendapat respon yang memadai, karena secara mendasar kekerasan terhadap perempuan dipahami hanya sebagai persoalan yang sifatnya personal, artinya apabila seorang perempuan menjadi korban sasaran tindak kekerasan, maka langsung dikaitkan dengan kepribadian, si korban dicari-cari hubungannya dengan perilaku korban dianggap mencetuskan tindak kekerasan tersebut. Hal ini serupa dengan mengatakan bahwa, jika perempuan mengalami tindak kekerasan, sedikit atau banyak dianggap terjadi karena andil kesalahan sendiri. jika korban menginginkan penanganan masalah yang menimpanya orang menganggap hal itu dapat diselesaikan secara pribadi oleh korban, paling jauh anjuran yang sering diterima perempuan korban adalah diselesaikan secara kekeluargaan, yang sesungguhnya berarti menghindari penanganan secara publik, maupun penyelesaian perkara secara hukum. (Purwanti, Hukum, \& Diponegoro, 2018)

Berdasarkan fenomena tersebut,diperlukan usaha-usaha yang rasional untuk menanggulangi kejahatan (politik kriminal). Politik kriminal (criminal policy) ini merupakan bagian dari politik penegakan hukum dalam arti luas (law enforcement policy). Semuanya merupakan bagaian dari politik sosial (sosial policy), yakni usaha dari masyarakat atau negara untuk meningkatkan 
kesejahteraan warganya.(Muladi ; Barda Nawawi Arief, 1992)

\section{B. Metode}

Dalam melakukan penelitian guna menunjang keakuratan data dalam rangka menyelesaikan penulisan skripsi ini, penelitian dilakukan dengan metode yuridis empiris. Pendekatan yang dilakukan tidak hanya berpegang pada segi yuridis saja melainkan dengan bantuan ilmu social lainnya. Yuridis sendiri merupakan metode penelitian yang berpegang pada hukum, peraturan perundang-undangan yang berlaku teori hukum dan pendapat para sarjana hukum yaitu penelitian terhadap data sekunder (law in the books). Empiris mengacu pada hal-hal nyata dan penerapan dalam masyarakat yaitu penelitian data primer (law in the action)

Spesifikasi penelitian yang dipergunakan dalam penelitian ini adalah deskriptif analitis, karena data yang diperoleh dari penelitian ini berusaha memberikan penjelasan dengan memberikan gambaran atau mengungkapkan berbagai faktor yang dipandang erat kaitannya dengan Pengakan Hukum Tindak Pidana Kekerasan Terhadap Perempuan di Kota Demak.

\section{Hasil dan Pembahasan \\ 1. Kebijakan Formulasi Perlindungan Bagi Perempuan}

Secara factual kondisi perlindungan dan penegakan HAM di Indonesia memang masih sangat memperihatinkan apalagi perlindungan trhadap hak-hak asasi perempuan.(Farida, 2012) Keberadaan hukum dalam masyarakat dapat di lihat dari bermacam-macam sudut, para professional hukum, seperti hakim, jaksa advokat akan melihat dan mengartikan hukum sebagai suatu perundang-undangan. Bagi mereka tidak adakeraguan bahwa hukum itu tampil dan ditentukan dalam wujud prundangundangan tersebut, di sini otoritas perundangundangan adalah demikian besar, dapat di katakana bahwa di luar undang-undang tidak ada hukum. Para profesional adalah golongan yuridis sebagai pemain, sehingga posisi mereka berhadapan dengan hukum. Kredo mereka adalah menyelesaikan soal dengan menerapkan undang-undang.(Widyastuti, 2011)

i. Kebijakan Formulasi Perlindungan Bagi Perempuan Dalam Instrument Hukum Internasional.

1. Convention On The Elimination Of All Forms Of Discrimination Against Women ( CEDAW)

Convention On The Elimination of All Forms Of Discrimination Against 
Women ( CEDAW) merupakan konvensi yang komprehensif yang`di akui dunia sebagai bill of Rights for Women, karena menekankan pada persamaan dan keadilan antaran perempuan dan lakilaki, yaitu persamaan hak dan kesempatan serta penikmatan manfaat di segala bidang kehidupan dan kegiatan, kesetaraan dalam CEDAW dimaknai bukan sebagai kesamaan di semua sector tetapi kesetaraan perlakuan dan kesempatan dalam dunia politik, ekonomi,social, dan lain-lain.(Patra, 2011)Tercantum di dalam Artikel $1,2,3,5$, dan 6 .

2. Declaration on the Elimination of Violence against Women

Declaration on the Elimination of Violence against Women ini mengatur mengenai tindak pidana kekerasan terhadap perempuan, namun deklarasi ini lebih mengatur upaya apa yang di lakukan oleh negara, organ dan badanbandan PBB yang bertujuan untuk penghapusan tindak kekerasan terhadap perempuan. Tercantum dalam Artikel 1,2,3,4,5, dan 6 .

2. Kebijakan Formulasi Perlindungan Bagi Perempuan Dalam Instrument Hukum Nasional.

a.Perundang-Undangan a. Undang-Undang Dasar Republik Indonesia 1945

Undang-Undang Dasar Republik Indonesia 1945 menekankan terhadap persamaan hak antara laki-laki dan perempuan dalam melakukan perlindungan hak asasi manusia tidak membedakan laki-laki dan perempuan yang tercantum dalam Pasal 28D, 28G, 28I, dan 28J.

b. Undang - Undang No 8 Tahun 1981 Tentang Kitab Undang-undang Hukum Pidana (KUHP )

Perlindungan terhadap perempuan dalam Undang - Undang No 8 Tahun 1981 Tentang Kitab Undang-undang Hukum Pidana (KUHP) hanya berlaku di luar lingkup rumah tangga setelah adanya Undang-undang No 23 Tahun 2014 Tentang Penghapusan Kekerasan Dalam Rumah Tangga. Kkerasan terhadap perempuan di bagi 3:

a) Kekerasan seksual tidak adanya marital rape (tindak pemerkosaan dalam perkawinan) yang tercantum Pasal 285, 286, 288, 294, dan 297.

b) Kekerasan psikis yang tercantum Pasal 310 sampai 318

c) Kekerasan fisik yang tercantum Pasal 338, 306, 353, 354, 355, dan 356. 
Peraturan materiil yaitu berupa delik (peraturan yang sifatnya mengatur tentang apa yang disebut sebagai kejahatan dan pelanggaran, unsur deliknya, dan sanksi), yang diatur dalam KUHP belum mengenal kekerasan berbasis gender. Hal ini terlihat dari rumusan-rumusan pasalpasal, misalya: tidak satupun pasal yang mengenal atau mengidentifikasikan kekerasan terhadap perempuan; pasal-pasal yang berkaitan dengan kejahatan seksual dikategorikan sebagai kejahatan kesusilaan dan bukan kejahatan atas integritas tubuh perempuan.

c. Undang-Undang Nomor 1 Tahun 1974

Undang- Undang Nomer 1 Tahun 1974 mempunyai dua sifat yaitu mengakui legal capacity kaum perempuan (istri), namun di pihak lain justru mengukuhkan sex roles dan gender stereotyping perempuan dan laki-laki membagi peran secara kaku peran perempuan di sector privat atau domestik. Kelemahan dalam undangundang ini karena telah mengkukuhkan pembagian kerja secara seksual dan stereotyping. Kekerasan dalam rumah tangga, beban kerja yang berlebihan dan tidak di akuinya perempuan sebagai kepala keluarga adalah akibat langsung adanya pembagian kerja seksual tersebut. Tercantum dalam Pasal 1, 30, 31, dan 33.

d. Undang-Undang Nomor 8 Tahun 1981 Tentang Kitab Undang-Undang Hukum Acara Pidana (KUHAP)

KUHAP adalah dasar peraturan perundang-udangan upaya penegakan hukum pidana yang di lakukan secara penal. Upaya penal(Sudarto, 1980) merupakan salah satu upaya penegakan hukum atau segala tindakan yang dilakukan oleh aparatur penegak hukum yang lebih menitik beratkan pada pemberantasan setelah terjadinya kejahatan yang dilakukan dengan hukum pidana yaitu sanksi pidana yang merupakan ancaman bagi pelakunya. Tercantum dalam Pasal 98 ayat 1, 184, dan 183.Seperti contoh kasus kekerasan dalam rumah tangga pembuktiannya agak sulit untuk memenuhi Pasal 184 karena kurangnya saksi, kebanyakan saksi yang ada adalah korban itu sendiri. Perlu adanya alat bukti berupa surat, dalam kasus kekerasan dalam rumah tangga alat bukti surat berbentuk visum etrepertum yang di buat oleh dokter. Dalam undang- undang ini minimal terdapat 2 alat bukti, 
sedangkan biasanya kasus kekerasan dalam rumah tangga terjadi di dalam rumah atau ruangan tertutup yang luput dari pandangan orang lain, keterangan korban saksi dan visum et repertum dapat sebagai alat bukti. (Peterson \& Bialo-Padin, 2012)

e. Undang-Undang Nomor 7 Tahun 1984 Tentang Pengesahan Konvensi Mengenai Penghapusan Segala Bentuk Diskriminasi Terhadap Wanita.

Undang-undang nomer 7 tahun 1984 ini adalah bentuk ratifikasi dari Convention of Elimination of All forms of Discrimination Against Women (CEDAW) sejak tahun 1984. Konvensi ini telah di ratifikasi oleh lebih dari 177 negara dan salah satunya Indonesia. Konsekuensi dari ratifikasi tersebut membuat pemerintah suatu negara harus melaksanakan upaya-upaya penghapusan brbagai bentuk diskriminasi terhadap perempuan.tercantum pada Pasal 15 dan 16.

Pada dasarnya isi konvensi tersebut sesuai dengan dasar negara pancasila dan undang-undang dasar 1945, yang menetapkan bahwa semua warga negara bersamaan kedudukannya di dalam hukum dan pemerintahan.
Pengaturan konvensi ini tidak mempengaruhi asas atau peraturan perundang-undangan yang sudah ada karena di dalam peraturan perundangundangan yang ada mengandung asas persamaan antara laki-laki dan perempuan sebagai perwujudan tata hukum Indonesia sudah baik dan sesuai dengan aspirasi masyarakat. Kekerasan terhadap perempuan selain merupakan pelanggaran hak asasi juga merupakan diskriminasi terhadap perempuan.(Moerti hadiati, 2010)

6) Undang - Undang Nomer 30 Tahun 1999 Tentang Hak Asasi Manusia

Bunyi pasal 3 Undang - Undang Nomer 30 Tahun 1999 Tentang Hak Asasi Manusia di pertegas dalam Pasal 4, Pasal 5, Pasal 20, Pasal 33 dan Pasal 34. Pasal 4 Undang-Undang Nomor 39 Tahun 1999 tersebut memiliki dasar pembentukan antara lain untuk melindungi, mempertahankan dan meningkatkan martabat manusia di perlukan pengakuan dan perlindungan hak asasi manusia. Tanpa hal tersebut maka manusia akan kehilangan sifat dan martabatnya, sehingga dapat mendorongagi manusia lainnya (homo homini lupus). Tindak kekerasan terhadap perempuan merupakan 
perbuatan yang tidak menghormati hak asasi orang lain.Pasal 45 menegaskan hak wanita dalam undang-undang adalah hak asasi manusia.

7)Undang-undang Nomor 23 Tahun 2004 Tentang Penghapusan Kekerasan Dalam Rumah Tangga.

Hukum pidana yang terdapat dalam UUPKDRT merupakan hukum pidana administratif.Undang-undang Nomor 23 Tahun 2004 Tentang Penghapusan Kekerasan Dalam Rumah Tangga pasal-pasal yang di paparkan di atas merupakan perbuatan-perbuatan yang dinyatakan sebagai tindak pidana antara lain kekerasan fisik Pasal 6, kekerasan psikis Pasal 7, kekerasan seksual Pasal 8 dan juga mengatur sanksinya. Sanksi fisik berada di Pasal 44 sanksinya, Pasal 45 mengatur sanksi mengenai psikis sedangkan Pasal 46, 47, 48 mengenai sanksi pidana kekerasan seksual. Ancaman pidana tambahan yang berada di Pasal 50.

Undang-Undang Nomer 23 Tahun 2004 ini tidak hanya terdapat ketentuan pidananya dan macam-macam bentuk kekerasan dalam rumah tangga yang berupa kekerasan fisik, seksual, psikis dan penelantaran, namun undangundang ini juga terdapat pengaturan mengenai hak-hak korban, perlindungan terhadap korban dan juga pemulihan korban. Kekerasan dalam rumah tangga tidak di anggap sebagai sebagai persoalan pribadi yang ruang lingkupnya hanya dalam rumah tangga saja. Maka dari itu undang-undang nomer 24 tahun 2004 dalam bab V mengenai kewajiban pemerintah dan masyarakat di perjelas pada Pasal 11.

8)Undang-undang Nomor 21 tahun 2007 Tentang Pemberantasan Tindak Pidana Perdagangan Orang

Undang-undang Nomor 21 tahun 2007 Tentang Pemberantasan Tindak Pidana Perdagangan Orang mengatur tindak pidana kekerasan terhadap perempuan, apa bila terjadinya tindak pidana perdagangan orang saja.Undang-undang ini menjelaskan mengenai kekerasan berupa kekerasan fisik, kekerasan psikis, dan perampasan kemerdekaan, sedangkan kekerasan seksual penjelasannya sebagai eksploitas seksual karena lebih mengarah terhadap memanfaatkan korban bukan hanya menyakiti saja. Undang-undang Nomer 21 tahun 2007 ini juga memfasilitasi korban dapat bersaksi tanpa hadirnya korban dengan menggunakan audio. Hal ini di lakukan 
untuk melindungi kesaksian korban agar kesaksian korban jelas dan asli. Tercantum pada Pasal 1 butir 1,3,7,8,11,12, Pasal 7, 12, 30, 34, 37, 45, 48, dan 51

b. Peraturan Daerah Provinsi.

1).Peraturan Daerah Provinsi Jawa Nomer 3 Tahun 2009 Tentang Penyelenggaraan Perlindungan Terhadap Korban Kekerasan Berbasis Gender dan Anak

Peraturan Daerah Provinsi Jawa Nomer 3 Tahun 2009 Tentang Penyelenggaraan Perlindungan Terhadap Korban Kekerasan Berbasis Gender dan Anak mengatur mengenai upaya pemerintah provinsi terhadap korban kekerasan terhadap perempuan dalam perlindungan korban, kewajiban pemerintah daerah dalam menangai tindak pidana kekerasan terhadap perempuan, upaya pencegahan dan juga upaya pemulihan korban namun tidak menyertakan sanksi pidana untuk pelaku tindak pidana kekerasan terhadap perempuan.

2).Peraturan Gubernur Jawa Tengah Nomor 18 Tahun 2014 Tentang Tata Cara Dan Persyaratan Pembentukan Pelayanan Terpadu Dan Komisi Perlindungan Korban Kekerasan
Berbasis Gender Dan Anak Provinsi Jawa Tengah

Peraturan Gubernur Jawa Tengah Nomor 18 Tahun 2014 Tentang Tata Cara Dan Persyaratan Pembentukan Pelayanan Terpadu Dan Komisi Perlindungan Korban Kekerasan Berbasis Gender Dan Anak Provinsi Jawa Tengah lebih menegaskan tentang bagaimana penanganan setelah terjadinya tindak pidana kekerasan terhadap perempuan. Lebih membahas cara mengatasi setelah terjadinya tindak pidana kekerasan terhadap perempuan dengan Pembentukan Pelayanan Terpadu Dan Komisi Perlindungan Korban Kekerasan Berbasis Gender Dan Anak Provinsi Jawa Tengah.

\section{Peraturan Daerah Kabupaten / Kota} a.Peraturan Bupati Demak Nomor 7 Tahun 2012 Tentang Pedoman Umum Pelaksanaan Penghasutan Gender Di Kabupaten Demak

Peraturan Bupati Demak Nomor 7 Tahun 2012 Tentang Pedoman Umum Pelaksanaan Penghasutan Gender Di Kabupaten Demak ini lebih menekankan terhadap pembangunan daerah yang berspektif gender karena adanya kesetaraan gender di dalamnya, 
kesetaraan gender adalah persamaan perlakuan antara laki-laki dan perempuan. Peraturan ini juga menekankan suatu proses untuk menjadi adil terhadap laki-laki perempuan terdapat dalam Pasal 1 butir 10,12,13,15, dan 16 .

Undang-undang ini memberikan perlindungan bagi premupan dalam hal membuat pembangunan daerah yang mensetarakan perempuan, maka perempuan mempunyai tempat atau kedudukan yang sada dengan laki-laki dan perempuan tidak dapat di padang lebih rendah oleh laki-laki.

2) Peraturan Daerah Kabupaten Demak Nomor 1 Tahun 2014 Tentang Penyelenggaraan Perlindungan Terhadap Korban Kekerasan Berbasis Gender Dan Anak

Peraturan Daerah Kabupaten Demak Nomor 1 Tahun 2014 Tentang PenyelenggaraanPerlindungan

Terhadap Korban Kekerasan Berbasis Gender Dan Anak Peraturan daerah ini lebih menekankan terhadap peraturan korban mulai dari perlindungan korban dan hak- hak korban sampai upaya pemulihan dan reintegrasi sosial, pengaturannya sudah cukup bagus tidak hanya penjelasan mengenai pengertian kekerasan berbasis gender saja terdapat pelayanan terpadu, perlindungan korban, hak korban, tujuan perlindungan, kewajiban pemerintah daerah upaya pencegahan dan partisipasi masyarakat. Tercantum dalam Pasal Pasal 1 (butir 5,10,11,13,17), Pasal 2,3,4,5,6,7,10,14,18,dan 19.

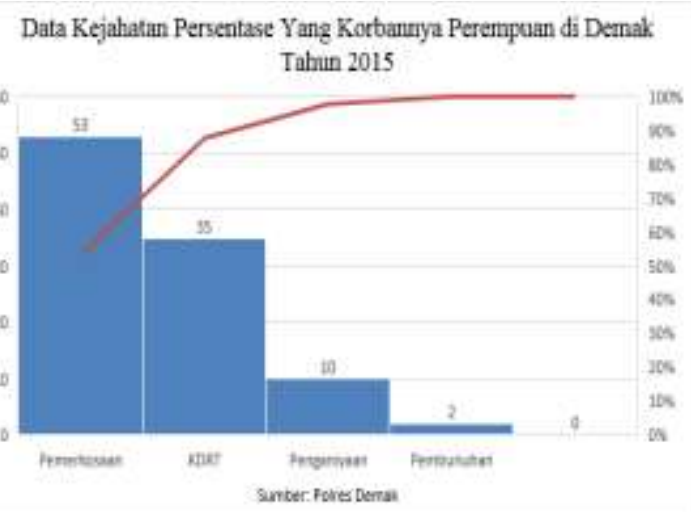

\section{Penegakan Hukum Tindak Pidana}

Kekerasan Terhadap Perempuan di Kota Demak.

i. Gambaran Umum Kota Demak

Demakmerupakan salah satu kabupaten di Jawa Tengah secara geografis terletak pada kordinat 6 derajat 43'26"- 7 derajat 09 "43" Lintang Selatan dan 110 derajat 27 "58"- 110 derajat 48"47" bujur timur.(Demak, n.d.)

Penegakan hukum pidana sebagai salah satu upaya penanggulangan 
kejahatan. Dalam operasionalisasi, aparat penegak hukum dalam upaya memberantas kejahatan dan menegakkan ketertiban/keamanan masyarakat dihadapkan pada masalah sulit. Bahkan terkadang dihadapkan pada situasi darurat yang sangat membahayakan kepentingan umum dan dirinya sendiri.(Arief, 1998)

Di kabupaten Demak mempunyai lembaga penegak hukumyaitu 1 Pengadilan Negeri Demak, 1 Pengadilan Agama, 1 Kejaksaan Negeri Demak dan 1 Polres Demak yang membawai 14 Polsek yaitu:
a. Polsek Kota Demak
b. Polsek Karangawen
c. Polsek Sayung
d. Polsek Mranggen
e. Polsek Karangtengah
f. Polsek Kebonagung
g. Polsek Dempet
h. Polsek Wonosalam
i. Polsek Karanganyar
j. Polsek Gajah
k. Polsek Mijen
1. Polsek Wedung
m. Polsek Bonang
n. Polsek Guntur

Terdapat 2 contoh putusan mengenai Kerasan Dalam Rumah Tangga yang pelakunya sama-sama di putus bersalah.

a. Kasus Pertama putusan Nomor.55/Pid.Sus.B/2015/PN.Dm k(Pengadilan Negeri Demak, n.d.b)

b. Kasus kedua putusan Nomor.91/Pid.Sus.B/2016/PN.Dm k(Pengadilan Negeri Demak, n.d.a)

2. Proses Penegakan Hukum Tindak Pidana Kekerasan Terhadap Perempuan di Demak.

1. Polres Demak

Polres Kota Demak mempunyai satuan unit yaitu unit PPA yaitu pelayanan perempuan dan anak. PPA ini di cakup dalam bagian reskrim. Sesuai dengan Peraturan Kepala Kepolisian Negara Republik Indonesia No. Pol: 10 tahun 2007 tentang Organisasi dan Tata Kerja Unit Pelayanan Perempuan dan Anak (UNIT PPA) di Lingkungan Kepolisian Republik Indonesia. Unit Pelayanan Perempuan dan Anak ini yang di singkat PPA adalah unit yang bertugas memberikan pelayanan, dalam bentuk perlindungan terhadap perempuan dan anak yang menjadi 
korban kejahatan dan penegakan hukum terhadap pelakunya. Unit PPA menyelenggarakan fungsinya yaitu:

1) penyelenggaraan pelayanan dan perlindungan hukum

2) penyelenggaraan dan penyidikan tindak pidana

3) penyelenggaraan kerjasama dan koordinasi dengan instansi terkait

Tindak pidana kekerasan dalam rumah tangga adalah termasuk tindak pidana kekerasan terhadap perempuan. Terdapat pada Pasal 6 ayat 3 dalam Peraturan Kepala Kepolisian Negara Republik Indonesia No. Pol: 10 tahun 2007 tentang Organisasi dan Tata Kerja Unit Pelayanan Perempuan dan Anak (UNIT PPA) di Lingkungan Kepolisian Republik Indonesia.

Menurut keterangan kepala unit PPA: Ipda Siswanto, S.pd. NRP: 82020316 kasus KDRT tahun 2015 di Kota Demak adalah 18 kasus dan penelantaran 3 kasus jadi permasalahan rumah tangga yang terjadi di Kota Demak dengan keterangan:

1) Masih dalam proses lidik 3 kasus (pelaku atau terlapor melarikan diri)

2) penyelesaian secara kekeluargaan 11 kasus
3) Tahap 2 atau pelimpahan kepada jaksa penuntut umum 7 kasus

Proses penegakan hukum tindak pidana kekerasan terhadap perempuan dengan kasus tindak pidana kekerasan dalam rumah tangga, yang di lakukan olehPolres kota demak unit PPA.

Pelaporan pertama di terima di SPK (Sentra Pelayanan Kepolisian) lalu di SPK akan di catat laporan tersebut, laporan tersebut di catat sebagai pengaduan terlebih dahulu atau laporan tertulis yaitu LP (Laporan Polisi) bilamana di catat sebagai LP nanti naik ke KASAT Reskrim (kepala kesatuan reserse kriminal) setelah itu di disposisikan kepada unit yang menangani perkara tersebut karena tindak pidana kekerasan dalam rumah tangga maka unit yang menangani perkara tersebut adalah unit PPA. Setelah di terima oleh KANIT PPA (kepala unit pelayanan perempuan dan anak) maka KANIT menunjuk penyidik yang akan menangani perkara tersebut. Setelah itu penyidik memanggil pelapor dan saksi-saksi perkara tersebut untuk di periksa, setelah di periksa lalu gelar perkara untuk memastikan unsur-unsurnya masuk atau tidak sehingga dapat di 
kembangkan perkaranya atau tidak. Apabila masuk maka di tindak lanjuti dengan PRINT SIDIK (Perintah Penyidikan) setelah PRINT SIDIK maka di lakukan pengambilan visum dan melengkapi berkas administrasi setelah lengkap memanggil terlapor sebagai saksi terlebih dahulu setelah memenuhi syarat dan alat bukti cukup maka di tempuh jalur mediasi terlebih dahulu bilamana tidak dapat mediasi maka di lanjutkan penyerahan berkas ke kejaksaan yaitu P 18 apabila berkas lengkap maka di nyatakan P21 proses selanjutnya adalah tahap 2 yaitu berkas perkara dan tersangka di serahkan ke kejaksaan.

Pendampingan pendampingan korban saat di BAP Polres kota demak pendampingnya dari PEKSOS (Pekerja Sosial) dan DINSOS P2PA (Dinas Sosial Pemberdayaan Perempuan dan Perlindungan Anak). Dalam kasus tindak pidana kekerasan terhadap perempuan dalam lingkup rumah tangga atau tindak pidana kekerasan dalam rumah tangga di kota Demak dalam catatan data unit PPA polres demak dari tahun 2015 semakin menurun karena ada 11 kasus. $^{1}$

2. Kejaksaan Negeri Demak

Undang-Undang Nomor 16 Tahun 2004 tentang Kejaksaan Republik Indonesia, Kejaksaan sebagai salah satu lembaga penegak hukum dituntut untuk lebih berperan dalam menegakkan supremasi hukum, perlindungan kepentingan umum, penegakan hak asasi manusia, serta pemberantasan Korupsi, Kolusi, dan Nepotisme $\quad(\mathrm{KKN}) . \quad$ Dalam melaksanakan kekuasaan negara di bidang penuntutan harus melaksanakan fungsi, tugas, dan wewenangnya secara merdeka, terlepas dari pengaruh kekuasaan pemerintah dan pengaruh kekuasaan lainnya.

Dalam menjalankan tugas dan wewenangnya, Kejaksaan berada pada posisi sentral dengan peran strategis dalam pemantapan ketahanan bangsa. Karena Kejaksaan berada di poros dan menjadi filter antara proses penyidikan dan proses pemeriksaan di persidangan serta juga sebagai pelaksana penetapan dan putusan pengadilan. Dengan

${ }^{1}$ Wawancara, dengan: Ipda Siswanto, S.pd , sebagai kepala unit PPA, NRP: 82020316, Pada tanggal 27 Januari 2017 
begitu Kejaksaan sebagai pengendali proses perkara (dominus litis), karena hanya institusi Kejaksaan yang dapat menentukan apakah suatu kasus/perkara dapat diajukan ke Pengadilan atau tidak berdasarkan alat bukti yang sah menurut Hukum Acara Pidana.

Kejaksaan juga memiliki tugas dan wewenang dalam bidang pidana lainnya yakni melakukan pengawasan terhadap pelaksanaan putusan pidana bersyarat, putusan pidana pengawasan, dan keputusan lepas bersyarat; melakukan penyelidikan terhadap tindak pidana tertentu berdasarkan undang-undang melengkapi berkas perkara tertentu dan untuk itu dapat melakukan pemeriksaan tambahan sebelum dilimpahkan ke pengadilan yang dalam pelaksanaannya dikoordinasikan dengan penyidik.

Menurut Nur Farida Anggraeni, S.H sebagai jaksa muda di kejaksaan negeri Demak ${ }^{2}$ menjelaskan bahwa tindak pidana kekerasan dalam rumah tangga tidak ada bagian tersendiri ikut di kelompokan di tindak pidana

${ }^{2}$ Wawancara, dengan Nur Farida Anggraeni, S.H sebagai jaksa muda di kejaksaan negeri Demak NIP : 197904202003122003, Pada tanggal 31 januari 2017 umum. Namun karena mempunyai undang-undang sendiri maka di kelompokan kodenya tersendiri yaitu tindak pidana umum lainnya. Proses penegakan hukum di kejaksaan Pasal 109 ayat (1) KUHAP: penyidik memberitahukan kejaksaan tentang dimulainya penyidikan dengan SPDP.

Berkas yang di nilai tidak cukup alasan untuk di limpahkan ke pengadilan maka jaksa mengeluarkan SP-3 sebab dapat di keluarkannya SP3 adalah tidak terdapat cukup bukti, perbuatan yang dilakukan tersangka atau terdakwa bukan perbuatan pidana, perkara ditutup demi hukum. Apabila memenuhin unsur-unsur di atas maka jaksa membuat surat dakwaan kemudian di limpahkan ke pengadilan dan menunggu jadwal sidang. Pertimbangan seorang jaksa dalam membuat suatu dakwaan dalam sebuah berkas perkara di lihat dari kualitas perbuatan terdakwa. Terhadap kasus kekerasan dalam rumah tangga di lihat apakah suami memukul istri menggunakan alat atau tidak karena akibatnya beda, seberapa sering melakukan hal tersebut, tersangka melakukan berbuatan tersebut mempunyai motif atau tidak, tentunya 
berbeda dengan bilamana istri menerima kekesaran karena seorang istri mempunyai kesalahan dengan seorang istri yang tidak mempunyai kesalahan. Akibatnya yang di timbulkan terdakwa apakah ringan ataupun berat. Tingkah laku terdakwa bilamana terdakwa bilamana terdakwa berbelit-belit dengan terdakwa sopan dan menyesali maka berbeda. Dan juga tidak lupa bertanya kepada korban dapat memaafkan terdakwa atau tidak. ${ }^{3}$

Kasus kekerasan dalam rumah tangga belum tentu mempunyai beban yang sama atau sama tuntutannya, walaupun kasus nya atau pelanggarannya sama. Asas Substansi dan Proportionaslitas yaitu berarti penjatuhan pidana itu bersifat sedang dan berat, ringan pidana harus sebanding dengan kejahatan. Maka dari itu seorang jaksa dalam membuat tuntutan atau surat dakwaan mempunyai pertimbangan seperti contoh terhadap kasus kekerasan dalam rumah tangga di lihat apakah suami memukul istri menggunakan alat atau tidak karena akibatnya beda,

${ }^{3}$ Wawancara, dengan Nur Farida Anggraeni, S.H sebagai jaksa muda di kejaksaan negeri Demak NIP : 197904202003122003 , Pada tanggal 31 januari 2017 seberapa sering melakukan hal tersebut, tersangka melakukan berbuatan tersebut mempunyai motif atau tidak, tentunya berbeda dengan bilamana istri menerima kekesaran karena seorang istri mempunyai kesalahan dengan seorang istri yang tidak mempunyai kesalahan. Dan juga akibat yang di timbulkan terdakwa apakah ringan ataupun berat. Tingkah laku terdakwa bilamana terdakwa bilamana terdakwa berbelit-belit dengan terdakwa sopan dan menyesali maka berbeda. Tidak lupa bertanya kepada korban dapat memaafkan terdakwa atau tidak. Bilamana terdapat 2 kasus tindak pidana kekerasan dalam rumah tangga yang sama persis namun terdakwa yang pertama melakukan dengan sengaja dan menimbulkan luka yang cukup berat namun terdakwa yang kedua melakukan tindak pidana ke kerasan dalam rumah tangga Karena ketidak sengajaan dan luka yang di terima korban tidak cukup berat maka kasus pertama dan kedua di dakwakan pasal yang sama namun terdakwa yang pertama mendapat batas maksial tuntutan yang berada dalam pasal tersebut dan terdakwa yang kedua mendapat tuntutan batas 
minimal dalam pasal tersebut. Dalam membuat surat dakwaan jaksa harus sangat mempertimbangan isi dakwaan nya Karena surat dakwaan merupakan dasar pemikiran dakwaan selanjutnya.

\section{Pengadilan Negeri Demak}

Pengadilan Negeri adalah suatu pengadilan yang memeriksa dan memutuskan perkara pidana dan perdata. Pengadilan negeri berkedudukan di ibu kota daerah kabupaten/kota. Daerah hukumnya juga meliputi wilayah kabupaten/kota. Pengadilan negeri bertugas adalah memeriksa, memutus, dan menyelesaikan perkara pidana dan perdata di tingkat pertama, serta dapat memberikan keterangan, pertimbangan, dan nasihat tentang hukum kepada instansi pemerintah didaerahnya apabila diminta. Pengadilan negeri Demak berdasarkan beberapa landasan hukum yang mengatur yaitu keputusan ketua mahkamah agung republic Indonesia nomor : 026/KMA/SK/II/2012 tentang standar pelayanan pengadilan,surat edaran direktur jendral badan peradilan umum nomor:3/DJU/HMO2.3/6/2014 tentang administrasi pengadilan berbasis teknologi informasi di lingkungan peradilan umum, peraturan mahkamah agung republik Indonesia nomor : 1 tahun 2008 tentang prosedur mediasi di pengadilan mahkamah agung republik Indonesia.

Narasumber ibu Novita Arie Dwi Ratnaningrum SH.,Sp.Not , sebagai Hakim di Pengadilan Negeri Demak ${ }^{4}$ dapat di simpulkan sebagai berikut. Pengadilan negeri Demak penanganan mengenai tindak pidana kekerasan terhadap perempuan, tindak pidana kekerasan seksual, fisik maupun psikis masuk ke ranah pidana umum, namun penanganan tindak pidana kekerasan dalam rumah tangga yang korban perempuan juga masuk ke dalam ranah pidana khusus karena mempunyai undang-undang khusus. Proses peradilan mulai dari pelimpahan dari kejaksaan berkas masuk ke bagian pidana untuk mengecek berkas dan barang bukti setelah semua lengkap naik untuk penunjukan majelis hakim oleh ketua pengadilan. Setelah itu di serahkan kepada panitera untuk menunjuk panitera pengganti lalu

\footnotetext{
${ }^{4}$ Wawancara, dengan Novita Arie Dwi Ratnaningrum SH.,Sp.Not , sebagai Hakim di Pengadilan negeri Demak NIP : 197611242005022001 , Pada tanggal 20 jaunari 2017
} 
berkas di bawa ke majelis hakim atau ketua majelis untuk penetapan hari sidang.

Pertimbangan hakim dalam menjalankan putusan mengambil fakta-fakta yang ada di persidangan. Fakta tersebut berdasarkan keterangan saksi, saksi dari korban maupun saksi dari tersangka dan di kaitkan alat bukti dan barang bukti lainnya. Jadi dari fakta yang berada dalam persidangan lalu di bandingkan dengan unsur-unsur yang di dakwakan. Hakim juga harus melihat status perkawinan ada atau tidak. Biasanya dalam kasus kekerasan dalam rumah tangga apa bila suami melakukan kekerasan tersebut suami satu-satunya tulang punggung keluarga dan juga istri sudah memaafkan hal tersebut dalam meringankan. Salah satu hambatan hakim yaitu apabila saksi tidak datang namun dalam BAP polisi sudah di sumpah dan saksi sudah di panggil 3 kali maka nanti akan di bacakan BAP nya. Ada kasus mengenai kekerasan dalam rumah tangga, korban atau istrinya memohon terhadap majelis hakim agar tersangka atau suaminya yang di laporkan sendiri tidak di penjara. Hal ini dapat meringankan tersangka.

Kekerasan dalam rumah tangga yang terjadi terhadap perempuan seringkali membingungkan putusan yang akan di jatuh kan oleh hakim. Karena sering korban sendiri yang memohon agar hukuman terdakwa di ringankan. Tindakan tersebut karena ketergantungan seorang perempuan terhadap suaminya. ${ }^{5}$

3. Pusat Pelayanan Terpadu

Pusat Pelayanan Terpadu di Demak di naungi atau di jalankan oleh Dinas Sosial Pemberdayaan Perempuan dan Perlindungan Anak (P2PA) sejak tahun 2015. Dahulu Berdiri sendiri yaitu Kantor Pemberdayaan Perempuan dan Perlindungan Anak (KP2PA) kemudian bergabung dengan Dinas Sosial menjadi Dinas Sosial Pemberdayaan Perempuan dan Perlindungan Anak (P2PA).Terdapat beberapa penangananpenanganan mengenai kekerasan berbasis gender tersebut salah satunya adalah Pusat Pelayanan Terpadu (PPT). Peraturan Daerah Kabupaten Demak Nomor 1 Tahun 2014 terdapat definisi

${ }^{5}$ Wawan cara, dengan Novita Arie DwiRratnaningrum SH.,Sp.Not , sebagai Hakim di Pengadilan negeri Demak NIP : 197611242005022001 , Pada tanggal 20 jaunari 2017 
atau pengertian mengenai Pusat Pelayanan Terpadu yaitu serangkaian kegiatan untuk melakukan perlindungan bagi korban kekerasan berbasis gender dan anak yang dilaksanakan secara bersama-sama oleh instansi atau lembaga terkait sebagai satu kesatuan penyelenggaraan, upaya pencegahan pelayanan kesehatan, rehabilitasi psikososial, pemulangan, reintegrasi sosial, dan bantuan hukum bagi korban kekerasan berbasis gender dan anak.

Kasi perlindungan perempuan dan anak Isyana dewi ${ }^{6}$ menjelaskan terdapat kasus kekerasan dalam rumah tangga terdapat 21 kasus dalam tahun 2015 namun hanya 2 saja yang melaporkan kepada Pusat Pelayanan terpadu karena rasa kurang percaya dan lebih mempercayai Pelayanan Perempuan Anak (PPA) polres.

Pusat Pelayanan Terpadu di Demak memiliki anggota atau berkerja sama dengan Kejaksaan Negeri Demak, Polres Unit Pelayanan Perempuan Anak (PPA), Rumah Sakit Umum Kalijaga, Rumah Sakit Jiwa Amegondo, juga mempunyai Advokat yang di gaji oleh pemerintah daerah, namun Advokat tersebut tidak

6 Wawancara,dengan Isyana Dewi, sebagai Kasi perlindungan perempuan dan anak NIP: 196808191994032007 selalu berada di Dinas Sosial Pemberdayaan Perempuan dan Perlindungan Anak (P2PA) karena minimnya gaji yang di berikan oleh pemerintah daerah. LBH Sultan Fatas sendiri telah mengundurkan diri sebagai anggota koordinator Pusat Pelayanan Terpadu di Demak. Pusat Pelayanan Terpadu di Demak memenuhi persyaratan menurut Peraturan Gubernur Jawa Tengah No 18 Tahun 2014 Tentang Tata Cara Dan Persyaratan Pembentukan Pelayanan Terpadu Dan Komisi Perlindungan Korban Kekerasan Berbasis Gender Dan Anak Provinsi Jawa Tengah untuk membentuk suatu lembaga yang berfungi melindungi korban yang utamanya perempuan dan anak yaitu Pusat Pelayanan Terpadu.

Pusat Pelayanan Terpadu di Demak berbeda koordinasi Pelayanan Terpadu tidak dilaksanakan melalui koordinasi pleno dan tidak diikuti oleh semua anggota nya. Pusat Pelayanan Terpadu di Demak akan melakukan pendampingan apabila di beri undangan oleh kejaksaan atau kepolisian saja. Polres Demak Unit Pelayanan Perempuan Anak (PPA) melaporkan setiap bulan nya jumlah kasus yang masuk ke Unit Pelayanan Perempuan 
Anak (PPA). Hakim di Pengadilan Negeri Demak dalam menangani kasus yang korbannya perempuan dan anak, hakim tidak pernah berkoordinasi dengan Pusat Pelayanan Terpadu (PPT). Pusat Pelayanan Terpadu (PPT) penanganan di bidang kesehatan selalu memberi bantuan terdahap PPT dalam penanganan korban penulis dapat mengatakan penanganan di bidang kesehatan seperti contoh penanganan pada kasus panti asuhan di Karangmlati Demak yang anaknya tidak di urus hanya di peralat untuk menerima sumbangan anak-anak tersebut psikisnya terganggu dan Rumah Sakit Jiwa Amenogondo ikut serta membantu korban dengan tanpa biaya sampai korban benar-benar pulih kembali. Di Demak rumah aman atau shelter tidak di sediakan namun bilamana ada korban yang membutuhkan, maka Pusat Pelayanan Terpadu (PPT) di Demak akan berusaha mencari tempat tinggal yang aman dan dapat di tinggali. Contoh pada tahun 2016 terdapat salah satu korban kekerasan dalam rumah tangga dan membutuh kan rumah aman atau shelter dan PPT Demak mengusahakan dan menyediakan.

\section{Kesimpulan}

Kebijakan formulasi mengenai tindak pidana kekerasan terhadap perempuan yang terdapat dalam Instrument Internasional yaitu Declaration on the Elimination of Violence against Women ini mengatur mengenai tindak pidana kekerasan terhadap perempuan, namun deklarasi ini lebih mengatur upaya apa yang di lakukan oleh negara, organ dan badanbandan PBB yang bertujuan untuk penghapusan tindak kekerasan terhadap perempuan. Kebijakan formulasi tindak pidana kekerasan terhadap prempuan dalam Instrumen Hukum Nasional yaitu UndangUndang Nomer 23 Tahun 2004 Penghapusan Tindak Pidana Kekerasan Dalam Rumah Tangga namun hanya mengatur tindak pidana kekerasan terhadap perempuan dalam ruang lingkup rumah tangga saja. Undang-undang Nomor 21 tahun 2007 Tentang Pemberantasan Tindak Pidana Perdagangan Orang mengatur tindak pidana kekerasan terhadap perempuan, apa bila terjadinya tindak pidana perdagangan orang saja. Peraturan Daerah Provinsi Jawa $\begin{array}{lllll}\text { Nomer } & 3 & \text { Tahun } & 2009 & \text { Tentang }\end{array}$ Penyelenggaraan Perlindungan Terhadap Korban Kekerasan Berbasis Gender dan Anak mengatur mengenai upaya pemerintah provinsi terhadap korban kekerasan terhadap perempuan dalam perlindungan korban, kewajiban pemerintah daerah dalam menangai 
tindak pidana kekerasan terhadap perempuan, upaya pencegahan dan juga upaya pemulihan korban namun tidak menyertakan sanksi pidana untuk pelaku tindak pidana kekerasan terhadap perempuan.

Penegakan hukum tindak pidana kekerasan terhadap perempuan dalam ruang lingkup rumah tangga di kota Demak belum optimal. Polres demak pada tahun 2015 sampai sekarang masih terdapat 3 kasus kekerasan dalam rumah tangga yang masih dalam proses lidik. Tidak ada upaya dari Polres Demak untuk menyelesaikan kasus tersebut. Hakim Pengadilan Negeri Demak dalam penjatuhan putusan terhadap kasus kekerasan dalam rumah tangga sering rancu di karenakan di temukan fakta dalam

\section{DAFTAR PUSTAKA}

Arief, B. N. (1998). Beberapa aspek kebijakan penegakan dan pengembangan hukum pidana. Bandung: Citra Aditya Bakti.

Demak, P. (n.d.). No Title. Retrieved from http://demakab.go.id/

Farida, E. (2012). Efektifitas Kelembagaan Komnas Perempuan Dalam Perlindungan Ham Bagi Perempuan Di Indonesia. Jurnal Masalah-Masalah Hukum, 41(4), 597. persidangan bahwa korban atau istri dari terdakwa memohon keringanan atas penjatuhan putusan terhadap terdakwa. Pusat Pelayanan Terpadu di Demak ini yang seharusnya melaksanakan tugasnya melalui koordinasi pleno pada kenyatannya Polres kota Demak hanya melaporkan jumlah kasus kekerasan dalam rumah tangga pertahunnya saja. Kejaksaan Negeri Demak memperbolehkan Pusat Pelayanan melakukan pendampingan apabila Pusat Pelayanan Terpadu Demak memperoleh undangan dari Kejaksaan Negeri Demak saja. Pusat Pelayanan Terpadu belum pernah melakukan koordinasi dengan Pengadilan Negeri Demak maupun Hakim dengan Pengadilan Negeri Demak
Foley, S., Ngo, H. Y., Loi, R., \& Zheng, X. (2015). Gender, gender identification and perceived gender discrimination: An examination of mediating processes in China. Equality, Diversity and Inclusion, $\quad 34(8), \quad 655$. http://doi.org/10.1108/EDI-05-20150038

Komnas Perempuan. (2016). No Title. Retrieved from http://www.komnasperempuan.go.id/sia 
ran-pers-komnas-perempuan-catatantahunan-catahu-2016-7-maret-2016/, diakses pada tanggal 25-9-2016

Moerti hadiati. (2010). Kekerasan Dalam Rumah Tangga. Jakarta: Sinar Grafika.

Muladi ; Barda Nawawi Arief. (1992). Bunga Rampai Hukum Pidana. Bandung: Alumni.

Patra, R. (2011). Implementasi prinsip pokok convention on the emilimation of all forms discrimination against women (cedaw) di Indonesia. Jurnal MasalahMasalah Hukum, 40(4), 445.

Pengadilan Negeri Demak. Berkas pidana putusan

Nomor.91/Pid.Sus.B/2016/PN.Dmk.

Demak.
Pengadilan Negeri Demak. Berkas pidana putusan Nomor55/Pid.Sus.B/2015/PN. Demak.

Peterson, R. R., \& Bialo-Padin, D. (2012). Domestic Violence Is Different: The Crucial Role of Evidence Collection in Domestic Violence Cases. Journal of Police Crisis Negotiations, 12(2), 105. http://doi.org/10.1080/15332586.2012.7 17047

Sudarto. (1980). Hukum dan Masyarakat, Cetakan Terakhir. Bandung: Angkasa.

Widyastuti, R. (2011). Kekerasan Dalam Rumah Tangga Dari Perspektif Hak Asasi Manusia. Jurnal MasalahMasalah Hukum, 40(1), 80-81. 